\title{
An Application of Structured Decision Making Process in Approaching Deforestation and Promoting Sustainable Forest Management of Sylhet, Bangladesh
}

\author{
A. F. M. Zakaria \\ Anthropology, \\ Shahjalal University of Science and Technology, \\ Bangladesh
}

\begin{abstract}
Deforestation is a global phenomenon with a critical recognition. It is very visible mostly in developing countries in Asia and Southern America. In many regions where forest loss is significant, so much effort has been garnered towards protecting the natural forest and promoting sustainable forest management (SFM). Evidence of such efforts includes the various policies, principles, and frameworks put in place both at the international and domestic levels. Despite these efforts, forest depletion continues to thrive at alarming rates particularly in developing countries like Bangladesh. This paper brings out a plethora of complex causes and consequences of deforestation in Sylhet, Bangladesh, with the principal objective of using a structured decision-making (SDM) approach to address deforestation in Sylhet through a pluralistic stakeholder engagement that represents all the objectives of the various groups in a very understandable manner. Mainly deploying FGD to consult with different stakeholder groups, representing different interests working through the steps of SDM, the consultations developed a SDM framework with suggested alternative approaches towards addressing deforestation in Sylhet, Bangladesh. Based on the judgments of the consultations, suitable policy options for addressing deforestation in Sylhet, Bangladesh should focus on maximizing forest management, minimizing dependence on forest resources, and Alternative ' $A$ ' (Safe guarding forest by improving forest management). This case study provides insights on how SDM can be implemented for SFM in Sylhet, as well as some challenges and opportunities encountered during the process.
\end{abstract}

\section{INTRODUCTION}

Sustainable forest management (SFM) is widely accepted as the new paradigm to manage forest ecosystems. Although various efforts have been made to define key components, guidelines, and principles, in support of its implementation, there is still a gap between theory and practice. To implement SFM, managers require a decision-making framework in which the values of constituents, objectives and performance measures are consistent and used to evaluate and choose between alternatives. Structured decision-making (SDM) is a systematic approach that can contribute to develop this framework for SFM. SDM is used to suggest alternative approaches to the SFM process in Sylhet, Bangladesh. This case study provides insights into how SDM can be implemented for SFM, as well as some challenges and opportunities encountered during the process.

\section{Definition and Background of Deforestation}

Deforestation involving the conversion of forested land to other uses, or a permanent reduction of canopy cover has attracted increasing international attention in recent years (Food and Agriculture Organization (FAO) of the United Nations (UN), 2001).The process of deforestation describes the complete long-term removal of forest cover (Angelsen and 
Kaimowitz, 1999). Tropical deforestation is considered the second largest source of anthropogenic greenhouse gas (GHG) emissions (Achard et al., 2002), and is expected to remain a major emission source in the future (MEA, 2005 cited in European Union (EU), 2010). Deforestation is said to be highest in Asia and Southern America after Africa (FAO, 2001). For instance, Africa accounted for a net loss of 4.0 million hectares per year and an average annual negative change rate of $-0.62 \%$ from 2000 to 2005 , a loss almost equal to the size of Belgium and equivalent to $0.3 \%$ of the entire Asian forest cover but Asia reported a net gain approximately 1.0 million hectares due to massive afforestation in China not true for all Asian countries (FAO, 2006). Deforestation is caused by multiple drivers and pressures on forest resources. They include clearing of forested land for agricultural uses, infrastructural development and wood extraction (Geist and Lambin, 2002). In contributing to deforestation, agricultural product prices coupled with a complex set of additional institutional and locationspecific factors can be extremely important in certain localities. Most importantly, the specific characteristics and magnitude of the socio-economic drivers behind deforestation vary widely across countries, regions and continents. Many forest scientists agree that agricultural expansion is the most important direct driver of land use change globally, followed by infrastructure development and wood extraction; international trade and shifting regional balance; mining for minerals; the influence of worldwide policy-making/governance and technological innovation; as well as demographic changes and associated pressures on natural resources (FAO, 2006). Estimates show that tropical deforestation and forest degradation emitted between 1 to 2 billion tons of carbon per year in the 1990s, equivalent to $15-25 \%$ of the annual global GHG emissions (Houghton, 2005). Deforestation impacts the climate and its associated phenomena like global warming, extreme weather events, flooding, desertification, sea level rise, El Nino, decline of glaciers and Artic ice. The Intergovernmental Panel on Climate Change (IPCC) has pointed out that for tropical countries, deforestation estimates are very uncertain and could be in error by as much as $\pm 50 \%$ (Achard et al., 2002).

Despite the policy efforts in some countries to reduce deforestation, around 13 million hectares of forests continue to be lost every year (FAO, 2010). Global forest assessments such as those undertaken by the FAO show that the humid tropical forests deserve special attention from policy makers because demographic, economic, and social changes continue to exert considerable pressure on forest cover, with the impacts felt mostly in developing nations(FAO, 2010). It is based on this assertion that this paper focuses on the SDM process as a suggestion for addressing deforestation in Bangladesh, a country with of the higher deforestation rates in Asia.

\section{Brief Overview of Forest Deforestation in Sylhet and Bangladesh}

Bangladesh is located in Southeast Asia, bordered by India and the Bay of Bengal. Bangladesh is once richly endowed with forest resources, which were vital for her development and economic prosperity. Originally, Bangladesh's forests covered about $25 \%$ of the total land mass of the country, but Bangladesh lost its 70 to 80 percent of her forest cover by the last century and it's annual deforestation rate increases from 1.82 ha to 2.6 ha between 2005 and 2010 (Chowdhury and Hossain, 2011). Many different factors have been reported as the causes of deforestation in Bangladesh (FAO, 2010; Chowdhury and Hossain, 2011). These factors include: population pressure, poverty, unemployment, excessive logging, unsustainable agricultural practices, unregulated industrialization, slash and burn agriculture, mining, hill cutting, quarrying, settlement expansion and infrastructural development.

The Sylhet Forest Division is bounded by the Khasia and Jainta Hills of India on the North; Patharia Hills, Tripura and Assam in the East; the international boundary with Tripura State of India and Brahmanbaria District in the West. There is about 13, $647 \mathrm{sq} . \mathrm{km}$. of total area in the 
greater Sylhet District. Out of this, the Forest Department administers $784.2 \mathrm{~km}^{2}$ (about 5.5\%) of area which are distributed as follows. For the purpose of managements, the forest areas of Sylhet will be divided into the following six working circles (Chowdhury et al, 2004) namely long rotation working circle, short rotation working circle, bamboo working circle, preservation and recreation working circle, reedlands working circle and miscellaneous working circle. Since 2005 co-management has been adopted in preservation circle but the pace of deforestation and degradation remain motionless. The National Biodiversity Strategy \& Action Plan for Bangladesh (October 2006) pointed out that the forest cover has come down to $6 \%$ from $10 \%$ of the area of the country and earlier it was about to $20 \%$.

Despite these setbacks, the Government of Bangladesh is committed to tackling deforestation and forest degradation. This was emphasized in the new Forest Policy in 2015, Five Year Plans and other on-going programs put in place to combat deforestation in Bangladesh. Some of these programs include: National Adaptation Program of Action (NAPA), Bangladesh Climate Change Strategy and Action Plan and more. Despite these efforts, the natural high forests all over the country are in depletion alarmingly. The problems of forest loss, coupled with inappropriate forest management and ineffective forest policies in Bangladesh, advocate a more comprehensive decision making approach to tackle the menace of deforestation in the country. In this context, the choice of the SDM process may show the way forward for addressing Sylhet's deforestation in a quest to promote SFM within the country.

The efforts of successive governments to address deforestation has yielded only limited successes, primarily because many of the initiatives were misguided and/or failed to deal with deforestation as a complex, dynamic and interlinked process (Yiridoe and Nanabg, 2001). In addition, attempts to address deforestation have stalled due to lack of collaboration between stakeholders and policy makers (Boafo. 2013). A more effective approach will therefore require an extensive inclusion of the different stakeholders, good cooperation between the stakeholder groups, including the integration of sustainable livelihood activities into national forestry policies. 




(Source: Public Domain, Google Image)

\section{Objective of the Study}

The general objective of this study is the structuring of decision-making to address deforestation in Sylhet, Bangladesh through a pluralistic stakeholder engagement that represents all the objectives of the various groups in a very understandable manner. This is going a long way to foster understanding on the link between forest resource use, deforestation, and forest management practices in Bangladesh. Following specific objectives make the general objectives clearer.

- Assess the existing policies related to forest management and identify the gap between policy and reality

- Identify the stakeholders in the field of forest and assess their priorities to formulate the objectives and evaluation criteria in addressing deforestation

- Incorporating the performance measures to track the outcome of their decisions

- Expose the uncertainties and showing tradeoffs relevant to the objectives in making the SDM a burgeoning field between stakeholders 
- Create alternatives in providing multi-options for multi-stockholders to reverse the current ratio of deforestation

\section{MATERIALS AND METHODS}

The study adopted a case study approach. This is because the approach pays attention to the forest of Sylhet, Bangladesh by considering the various issues and thoroughly reporting them. An in-depth examination of the deforestation situation in Sylhet, Bangladesh is done which informed the SDM approach.

A literature survey is conducted to synthesize empirical studies in order to examine the causes and consequences of deforestation in Sylhet, Bangladesh. This literature study answers some questions about the nature, extent, and more importantly, the causes and effects of deforestation in Sylhet. Both primary and secondary data is used for finding the gap between policy and management and to provide a holistic participatory framework to minimize the gap. The primary data consist of government and non-governmental reports relating to deforestation and mainly the outcome of thirty in-depth interviews, eight focused group discussions and public consultation while the secondary data mainly involve both published and unpublished reports, journals, articles and books on topics and researches relating deforestation and SDM. Purposive sampling has been applied to select the informant and stakeholders, who is the primary respondent of this study.

In data analysis, this project is descriptive and interpretative by nature. For the purpose of a better understanding, each of the components of SDM and its results are first defined, followed by the presentation of their individual make-ups, use a logical framework approach (LFA). The LFA is a management tool used largely to design and evaluate international development program, developed in 1969 for the United States Agency for International Development (USAID), based on a global study by Leon J. Rosenberg (North American Aerospace Command, 1999).

\section{The SDM Approach}

The SDM approach was mainly used in coming out with the decisions using participatory approach, and it adapted a logical framework approach (LFA). The steps in the SDM included:

- Clarification of the Decision Context: The problem of deforestation was identified and justified at this stage. The scope and bounds of the problem were digested.

- Formulation of Objectives and Evaluation Criteria: Together they defined "what matters" about the problem and decision to be made, and drove the search for creative alternatives. The evaluation criteria or performance measures defined the ways through which the outcomes will be measured. The objectives (fundamental objectives) and performance measures collectively became the frame for comparing alternatives.

- Incorporating Uncertainties: The probable uncertainties surrounding SFM policies through SDM in Bangladesh were identified.

- Development of Alternatives: A range of creative policies or management alternatives designed in an attempt to reduce the uncertainties surrounding SFM was developed.

- Estimation of Consequences: The performance of each alternative towards realizing the overall objective was estimated using the evaluation criteria developed at the second step.

- Evaluation of Trade-Offs and Suggesting best Policy Option: The discussions of the group played a central role in evaluating preferences for alternatives.

- Implementation and Monitoring: Mechanisms for on-going monitoring to ensure accountability with respect to current results, research to improve the information base 
for future decisions, and a review system to enhance the incorporation of new information into future decisions were identified at this stage.

\section{Tools and Techniques}

Several SDM tools were used in the analysis and presentation of data. These tools include:

- Pairwise Ranking: This tool, often used by social scientists was deployed as a means of prioritizing or ranking the fundamental objectives.

- Influence Diagrams: Influence diagrams are a conceptual modeling tool. This was graphically used to represent the causal relationships between decisions, external factors, uncertainties and outcomes.

- Consequence Table: This was used to estimate the consequences of each of the objectives.

- Likert Scale: The Likert scale is based on value judgment. This scales was used to define the consequences of both the fundamental objectives and the alternatives.

\section{RESULTS}

This chapter presents the results, which include the various stakeholders that were identified in the SDM process, the fundamental objectives, means objectives, process objectives, consequences, and the performance measures. For the purpose of a better understanding, each of the components of the results are first defined, followed by the presentation of their individual make-ups, using a logical framework approach (LFA). The LFA is a management tool used largely to design and evaluate international development, developed in 1969 for the United States Agency for International Development (USAID), based on a global study by Leon J. Rosenberg (North American Aerospace Command, 1999). The core of the LFA (which is the temporal logic model) is the main part that has been adopted in presenting the results of the SDM process of this paper because it provides clear linkages between the various categories of objectives, consequences and the performance measures. The temporal logic model holds that, for a particular project, if a given set of activities are implemented, and the stated assumptions hold, then the stated outputs will be delivered. If these outputs are delivered, and the stated assumptions hold, then the stated purpose will be achieved. And if this purpose is achieved, and these assumptions hold, then the stated goal will be achieved (North American Aerospace Command, 1999). In the SDM process presented in this paper, the activities represent the means and process objectives for each fundamental objective, while the assumptions are that these activities are implemented as indicated. The outputs are the consequences, while the purpose is the fundamental objective in each case, and the goal is to address deforestation of Sylhet, Bangladesh.

\section{Stakeholder Identification}

The stakeholders are divided into two categories: governmental and non-governmental stakeholders including their various roles. Deployments of FGD/Public consultation are the crucial for the purpose of the SDM exercise. 
Table 1: The Stakeholders and their Roles in the SDM Process

\begin{tabular}{|c|c|}
\hline Stakeholders & Their Roles \\
\hline \multicolumn{2}{|c|}{ Governmental Stakeholders } \\
\hline $\begin{array}{l}\text { Ministry of Environment and Forest } \\
\text { (Department of Forest and Department of } \\
\text { Environment) }\end{array}$ & $\begin{array}{l}\text { Formulation of policy, enhancing institutional } \\
\text { coordination, Implementation, monitoring } \\
\text { and evaluation of SDM }\end{array}$ \\
\hline Ministry of Planning & $\begin{array}{l}\text { Provision of technical advice and knowledge } \\
\text { relating to protecting the natural forest. }\end{array}$ \\
\hline Ministry of Local Governments & $\begin{array}{l}\text { Supervision of the activities that will be } \\
\text { implementing at the local levels. }\end{array}$ \\
\hline Ministry of Finance & $\begin{array}{l}\text { The ministry is in charge of release of funds } \\
\text { means for decision-making and } \\
\text { implementation from the government coffers. }\end{array}$ \\
\hline $\begin{array}{l}\text { Ministry of Law, Justice and Parliamentary } \\
\text { Affairs }\end{array}$ & $\begin{array}{l}\text { The legislative body will be in charge of } \\
\text { legislations (Acts and Laws) relating to } \\
\text { protecting the natural forest. }\end{array}$ \\
\hline Ministry of Home Affairs & $\begin{array}{l}\text { This ministry is responsible for providing the } \\
\text { support to implementing the laws related to } \\
\text { forest }\end{array}$ \\
\hline Ministry of Industries & $\begin{array}{l}\text { This ministry is responsible for transforming } \\
\text { forest and agricultural land into industry }\end{array}$ \\
\hline Ministry of Agriculture & $\begin{array}{l}\text { This ministry administers agricultural land } \\
\text { and formulating policy }\end{array}$ \\
\hline \multicolumn{2}{|c|}{ Non-Governmental Stakeholders } \\
\hline $\begin{array}{l}\text { The civil society Faith Based Organizations } \\
\text { (FBOs) and Community Based Organizations } \\
\text { (CBOs) }\end{array}$ & $\begin{array}{l}\text { These are located at the community levels. } \\
\text { They will contribute in terms of education on } \\
\text { issues relating to deforestation. }\end{array}$ \\
\hline Indigenous/Ethnic Community Leaders & $\begin{array}{l}\text { They are the custodians of the communal } \\
\text { lands in Bangladesh. Protecting the natural } \\
\text { forest is a matter of much concern to them. }\end{array}$ \\
\hline Chamber of Commerce & $\begin{array}{l}\text { Representation of the interest of their } \\
\text { members and ensuring strict compliance to } \\
\text { the decision's relating to the natural forest. }\end{array}$ \\
\hline $\begin{array}{l}\text { Academia and other interested research } \\
\text { institutes and bodies }\end{array}$ & $\begin{array}{l}\text { Contribute in terms of research towards } \\
\text { protecting the natural forest. }\end{array}$ \\
\hline Mining and logging companies & $\begin{array}{l}\text { Representation of the interest of their } \\
\text { members and ensuring strict compliance to } \\
\text { the decision's relating to the natural forest. }\end{array}$ \\
\hline The media & $\begin{array}{l}\text { Education and dissemination of information } \\
\text { relating to forest protection. }\end{array}$ \\
\hline
\end{tabular}

\section{Source: Constructed from the FGDs and Interviews (2017-18)}

\section{The Fundamental Objectives}

These are very simple, highly precise and independent statements covering aspects of importance to the various stakeholder groups (Gregory et al., 2012). In the case presented in this paper, they include the four fundamental objectives below:
(A) Minimize Dependence on Forest Resources
(B) Improve the state of biodiversity
(C) Maximize Forest Management
(D) Minimize forest and land degradation 


\section{Means Objectives}

These are the next sub-objectives that define the fundamental objectives by stating what could be done to achieve the mentioned fundamental objectives as presented on table 2. Because they enhance clarity, they are meant to avoid vagueness on the fundamental objectives (Gregory et al., 2012).

Table 2: Fundamental and Means Objectives

\begin{tabular}{|l|l|}
\hline \multicolumn{1}{|c|}{ Fundamental Objectives } & \multicolumn{1}{c|}{ Means Objectives } \\
\hline Minimize Dependence on Forest Resources & $\begin{array}{l}\text { Promote the adoption of the principles of green } \\
\text { economy in national development planning. }\end{array}$ \\
\hline Improve the state of biodiversity & $\begin{array}{l}\text { i. Maintain ecological integrity of protected } \\
\text { areas. } \\
\text { ii. Revise existing protected areas management } \\
\text { plan to intensify local participation in resource } \\
\text { management. }\end{array}$ \\
\hline Maximize Forest Management & $\begin{array}{l}\text { i. Coordinate and harmonize relevant policies } \\
\text { and programs with regional and international } \\
\text { bodies. } \\
\text { ii. Strengthen institutional and regulatory } \\
\text { frameworks regarding forest management. } \\
\text { iii. Integrate Strategic Environmental } \\
\text { Assessment (SEA) tools in the plan. } \\
\text { iii. Enact Legislative Instrument on tree tenure. }\end{array}$ \\
\hline Minimize forest and land degradation & $\begin{array}{l}\text { i. Vigorously pursue reclamation and } \\
\text { afforestation in degraded areas. } \\
\text { ii. Accelerate the implementation of national } \\
\text { buffer zone policies for rivers and protected } \\
\text { areas. }\end{array}$ \\
\hline
\end{tabular}

Source: Constructed from the FGDs and Interviews (2017-18)

\section{Objective Hierarchy}

After stating the fundamental and means objectives, there was need to present them in order of hierarchy to demonstrate the level of importance placed on each of the fundamental objectives using pairwise ranking. Pairwise ranking is a process used in the scientific study of preferences, attitudes, voting systems, social and public choice, to compare entities in pairs based mainly on valued judgments to decipher which entity is preferred, or has a greater value, depending on the number of times it appears on the table (David, 1988). Table 3 presents the results. On the table, each fundamental objective has been given alphabetical tag to simplify understanding. 
Table 3: Deciding Hierarchy of Importance of the Fundamental Objectives

\begin{tabular}{|c|c|c|c|c|}
\hline & $\begin{array}{c}\text { Minimize } \\
\text { Dependence on } \\
\text { Forest Resources } \\
\text { (A) }\end{array}$ & $\begin{array}{l}\text { Improve the } \\
\text { state of } \\
\text { biodiversity } \\
\text { (B) }\end{array}$ & $\begin{array}{l}\text { Maximize Forest } \\
\text { Management } \\
\text { (C) }\end{array}$ & $\begin{array}{l}\text { Minimize forest } \\
\text { and land } \\
\text { degradation } \\
\text { (D) }\end{array}$ \\
\hline $\begin{array}{l}\text { Minimize } \\
\text { Dependence on } \\
\text { Forest Resources } \\
\text { (A) }\end{array}$ & & A & $\mathrm{C}$ & A \\
\hline $\begin{array}{l}\text { Improve the } \\
\text { state of } \\
\text { biodiversity } \\
\text { (B) }\end{array}$ & A & & $\mathrm{C}$ & D \\
\hline $\begin{array}{l}\text { Maximize Forest } \\
\text { Management (C) }\end{array}$ & $\mathrm{C}$ & $\mathrm{C}$ & & $\mathrm{C}$ \\
\hline $\begin{array}{l}\text { Minimize forest } \\
\text { and land } \\
\text { degradation } \\
\text { (D) }\end{array}$ & $\mathrm{A}$ & $\mathrm{D}$ & $\mathrm{C}$ & \\
\hline
\end{tabular}

Source: Constructed from the FGDs (2017-18)

Based on valued judgments of the stakeholders, figure 3 shows that $(C)$ appears the most amount of times followed by (A), then (D), with the least being (B) since it does not appear even once. Therefore, in order of hierarchy, the fundamental objectives are as follows: maximize of forest management, minimize dependence on forest resources, minimize forest and land degradation, and improve the state of biodiversity. From this point, further presentations of the fundamental objectives respect this hierarchy.

\section{The Process Objectives}

These are the modes of operations through which the means objectives, and hence fundamental objectives, are realized (Gregory et al., 2012). In presenting the process objectives, the fundamental and means objectives have been repeated for the purpose of establishing very clear linkages between the three, as defined by the temporal logic model. 
Table 4: Incorporating the Process Objectives

\begin{tabular}{|c|c|c|}
\hline Fundamental Objectives & $\begin{array}{c}\text { Alternatives/Means } \\
\text { Objectives }\end{array}$ & $\begin{array}{c}\text { Process/operational } \\
\text { objectives }\end{array}$ \\
\hline Maximize forest management & $\begin{array}{l}\text { i. Coordinate and harmonize } \\
\text { relevant policies and } \\
\text { programs with regional and } \\
\text { international bodies. } \\
\text { ii. Strengthen institutional and } \\
\text { regulatory frameworks } \\
\text { regarding forest management. } \\
\text { iii. Integrate Strategic } \\
\text { Environmental Assessment } \\
\text { (SEA) tools in the plan. } \\
\text { iii. Enact Legislative } \\
\text { Instrument on tree tenure. }\end{array}$ & $\begin{array}{l}\text { i. Enhance coordination } \\
\text { among key government } \\
\text { agencies and other } \\
\text { stakeholders. } \\
\text { ii. Organize training sessions } \\
\text { for regulatory bodies and } \\
\text { provision of necessary } \\
\text { logistics. } \\
\text { iii. Enforcement of Legislative } \\
\text { Instruments on tree tenure. } \\
\text { iv. Enhancing training } \\
\text { programs to build capacity in } \\
\text { using SEA tools and other } \\
\text { novel tools like the Open Foris. }\end{array}$ \\
\hline $\begin{array}{l}\text { Minimize Dependence on } \\
\text { Forest Resources }\end{array}$ & $\begin{array}{l}\text { Promote the adoption of the } \\
\text { principles of green economy in } \\
\text { national development } \\
\text { planning. }\end{array}$ & $\begin{array}{l}\text { i. Revise and enforce Mining } \\
\text { and Environmental Guidelines. } \\
\text { ii. Facilitate alternative } \\
\text { livelihood like micro credits } \\
\text { and apprenticeship. } \\
\text { iii. Introduce ecotourism } \\
\text { support scheme. }\end{array}$ \\
\hline $\begin{array}{l}\text { Minimize forest and land } \\
\text { degradation }\end{array}$ & $\begin{array}{l}\text { i. Vigorously pursue } \\
\text { reclamation and afforestation } \\
\text { in degraded areas. } \\
\text { ii. Accelerate the } \\
\text { implementation of national } \\
\text { buffer zone policies for rivers } \\
\text { and protected areas. }\end{array}$ & $\begin{array}{l}\text { i. Enforcing mandatory } \\
\text { afforestation and land } \\
\text { reclamation for mining and } \\
\text { logging companies. } \\
\text { ii. Ensure strict compliance } \\
\text { from mining and logging } \\
\text { companies. } \\
\text { iii. Using financial sanctions } \\
\text { against encroachers. } \\
\text { iv. Introduce environmental } \\
\text { education programs. }\end{array}$ \\
\hline $\begin{array}{l}\text { Improve the state of } \\
\text { biodiversity }\end{array}$ & $\begin{array}{l}\text { i. Maintain ecological integrity } \\
\text { of protected areas. } \\
\text { ii. Revise existing protected } \\
\text { areas management plan to } \\
\text { intensify local participation in } \\
\text { resource management. }\end{array}$ & $\begin{array}{l}\text { i. Implement afforestation } \\
\text { based on local flora and fauna. } \\
\text { ii. Actively involve indigenes in } \\
\text { forest management programs. }\end{array}$ \\
\hline
\end{tabular}

Source: Constructed from the FGDs and Interviews (2017-18)

\section{Attributing Consequences to Objectives}

Consequences were first characterized and defined using the Likert scale before attributing them to the objectives. Likert scale is a bipolar scaling method which measures either a positive or negative response to a statement (Christopher et al., 2007). It uses the Likert item which is a statement that the respondent is required to evaluate based on any kind of subjective or objective criteria, and it is considered symmetric because of equal numbers of positive and negative positions (Burns and Burns, 2008). However, as shall be seen, no judgment amounted to the scale of -2 , so it was never used as an attribute to any means objective. 
Table 5: Defining Scales for Characterizing Consequences using the Likert Scale

\begin{tabular}{|c|c|c|c|c|c|}
\hline Scales & -2 & -1 & 0 & 1 & 2 \\
\hline Definitions & Very $(-)$ & Negative $(-)$ & Neutral $(0)$ & Positive $(+)$ & Very $(+)$ \\
\hline Explanations & $\begin{array}{c}\text { Highly } \\
\text { negative } \\
\text { impact on } \\
\text { the } \\
\text { objectives }\end{array}$ & $\begin{array}{c}\text { Negative } \\
\text { impact on the }\end{array}$ & $\begin{array}{c}\text { Have no } \\
\text { impact on the } \\
\text { overall } \\
\text { objectives }\end{array}$ & $\begin{array}{c}\text { Contributes } \\
\text { in realizing } \\
\text { overall } \\
\text { objectives }\end{array}$ & $\begin{array}{c}\text { Contributes } \\
\text { strongly in } \\
\text { realizing } \\
\text { overall } \\
\text { objective }\end{array}$ \\
\hline
\end{tabular}

Source: Constructed from the FGDs (2017-18)

\section{Indicating Outcomes and Identifying Performance Measures (PMs)}

After characterizing and defining scales for the consequences, they were then attributed mainly to the means objectives. In doing so, the outcomes were indicated and PMs identified. The attributes beside the various means objectives indicate how they impact their fundamental objectives. The choices of PMs could be natural (simple direct measurable outcomes like numbers), proxy (using another factor as a representative measure of an outcome) and/or constructed (formulating PMs for outcomes that are not easily measurable) (Gregory et al., 2012). For the purpose of better comprehension, natural PMs have been used in this case treated in this paper. 
Table 6: Indicating Outcomes and Identifying Performance Measures (PMs)

\begin{tabular}{|c|c|c|}
\hline \multicolumn{3}{|c|}{ Maximize Forest Management } \\
\hline Means objectives & Outcomes & Performance Measures \\
\hline $\begin{array}{l}\text { Coordinate and harmonize } \\
\text { relevant policies and } \\
\text { programs with regional and } \\
\text { international bodies (very +) }\end{array}$ & $\begin{array}{l}\text { Forestry policies and } \\
\text { programs with regional and } \\
\text { international coordinated } \\
\text { bodies are harmonized }\end{array}$ & $\begin{array}{l}\text { i. Number of effective } \\
\text { International/Regional } \\
\text { treaties signed within } 4 \text { years. } \\
\text { ii. Number of forestry } \\
\text { programs implemented }\end{array}$ \\
\hline $\begin{array}{l}\text { Strengthen institutional and } \\
\text { regulatory frameworks } \\
\text { regarding forest management } \\
\text { (very +) }\end{array}$ & $\begin{array}{l}\text { Institutional and regulatory } \\
\text { frameworks } \\
\text { regarding forest management } \\
\text { strengthened }\end{array}$ & $\begin{array}{l}\text { i. Number of competent } \\
\text { personnel available to fill } \\
\text { vacancies/year } \\
\text { ii. Availability of required } \\
\text { logistics in each department }\end{array}$ \\
\hline $\begin{array}{l}\text { Integrate Strategic } \\
\text { Environmental Assessment } \\
\text { (SEA) tools in the plan (very } \\
+ \text { ) }\end{array}$ & $\begin{array}{l}\text { Strategic Environmental } \\
\text { Assessment } \\
\text { (SEA) tools integrated in } \\
\text { development plans }\end{array}$ & $\begin{array}{l}\text { i. Number of districts and } \\
\text { regional plans containing SEA } \\
\text { tools } \\
\text { ii. Number of district annual } \\
\text { action plans subjected through } \\
\text { SEA }\end{array}$ \\
\hline $\begin{array}{l}\text { Enact Legislative Instrument } \\
\text { on tree tenure }(+)\end{array}$ & $\begin{array}{l}\text { Legislative Instrument on tree } \\
\text { tenure enacted }\end{array}$ & $\begin{array}{l}\text { i. Number of districts with } \\
\text { bylaws on tree tenure } \\
\text { ii. Number of people aware of } \\
\text { the bylaws }\end{array}$ \\
\hline \multicolumn{3}{|c|}{ Minimize Dependence on Forest Resources } \\
\hline Means Objectives & Outcomes & Performance Measures \\
\hline $\begin{array}{l}\text { Promote the adoption of the } \\
\text { principles of green economy in } \\
\text { national development } \\
\text { planning (very +) }\end{array}$ & $\begin{array}{l}\text { Principles of green economy } \\
\text { adopted (economic, social and } \\
\text { environmental benefits) }\end{array}$ & $\begin{array}{l}\text { i. Number and types of } \\
\text { alternative income generating } \\
\text { activities introduced } \\
\text { ii. Number of people } \\
\text { benefiting from alternative } \\
\text { activities per year } \\
\text { iii. Number of households } \\
\text { using alternative energy } \\
\text { sources }\end{array}$ \\
\hline \multicolumn{3}{|c|}{ Minimize forest and land degradation } \\
\hline Means objectives & Outcomes & Performance Measures \\
\hline $\begin{array}{l}\text { Accelerate the implementation } \\
\text { of national buffer zone policies } \\
\text { for rivers and protected areas } \\
\text { (+) }\end{array}$ & $\begin{array}{l}\text { National buffer zone policies } \\
\text { implemented }\end{array}$ & $\begin{array}{l}\text { i. Number of buffer zones } \\
\text { created } \\
\text { ii. Size of buffer zones in } \\
\text { hectares }\end{array}$ \\
\hline
\end{tabular}

\begin{tabular}{|l|l|l|}
\hline \multicolumn{3}{|c|}{ Improve the state of biodiversity } \\
\hline \multicolumn{1}{|c|}{ Means Objectives } & \multicolumn{1}{|c|}{ Outcomes } & \multicolumn{1}{c|}{ Performance Measures } \\
\hline $\begin{array}{l}\text { Maintain ecological integrity } \\
\text { of protected areas (very +) }\end{array}$ & $\begin{array}{l}\text { i. Activities of encroachers are } \\
\text { reduced } \\
\text { ii. Natural state of biodiversity } \\
\text { is maintained }\end{array}$ & $\begin{array}{l}\text { i. Percentage of protected } \\
\text { areas maintained from any } \\
\text { kind of threat } \\
\text { ii. Number of fire fighter units } \\
\text { trained and/or certified }\end{array}$ \\
\hline $\begin{array}{l}\text { Revise existing protected } \\
\text { areas management plan to } \\
\text { intensify local participation in } \\
\text { resource management (+) }\end{array}$ & $\begin{array}{l}\text { Local views are incorporated } \\
\text { into protected area plans }\end{array}$ & $\begin{array}{l}\text { i. Number of participation fora } \\
\text { organized per year }\end{array}$ \\
\hline
\end{tabular}




\section{DISCUSSION}

Forest is one of the most important renewable resources in the world and a great source of carbon sink. Mounting demands on forests resources from multiple sectors present significant challenges to forest and environmental protection because of the difficulty to strike a balance between the demands and need to protect this important resource. The past abundance of forest products has evolved into present day limitations, and if positive changes are not made, the present limitations will become future scarcities (Maser, 1994). The 1992 Rio Declaration drew international attention to this issue very loudly, and since then, several organizations, especially the Food and Agriculture Organization (FAO), have taken the lead in promoting policy directives and initiatives designed to encourage sustainable management of forests on a global scale (Maser, 1994). A recent typical example is the FAO Open Foris tool launched on October $10^{\text {th }} 2014$ at Rome, Italy $(F A 0,2014)$. The Open Foris tool is designed to improve the way countries (especially the developing nations) monitor the state of their forests to tackle deforestation and climate change by assisting them through the entire lifecycle of a forest inventory - from assessment, design and field data collection to analysis and reporting (FAO, 2014). With Open Foris piloting programs ongoing in more than ten countries in Africa, Asia, and Latin America. Bangladesh could also make use of the practicability of this tool in its forest management. Most countries have implemented other forestry management strategies in recognition of the critical importance of their forest resources. SFM requires the active participation, integration and coordination of every stakeholder, from decision sketch to policy implementation. Without incorporating all vested parties, the concept of sustainability would be very difficult to realize. These features and factors are especially important in developing countries where effective and enforceable forest policies have historically been lacking.

In the case of Sylhet, Bangladesh, the overall situation is worsening when compared with other developing countries in Asia and Africa. With the assistance of international agencies, the government of Bangladesh has already adopted some policies and measurements to stop the situation. However, for the most part, the initiatives are on paper not in the field. It was established that, the major reasons for policy failures in Bangladesh include institutional management deficiencies, lack of cooperation between different sectors (overlapping and overloaded policies), and lack of political commitment, inappropriate policy instruments, poor coordination, and dependency on external financial and technical assistance, corruptions, and most importantly the disengagement of local stakeholders. In 2016, the government of Bangladesh updated the forestry master plan where they also emphasized the consolidation of good governance through accountability and transparency, and the enhancement of active participation of indigenous and forest communities in resource management including addressing issues on land ownership, tree tenure and benefit sharing (Government of Bangladesh, 2016). However, in practice, the problem is the same as with previous initiatives that, authorities did not engage and incorporate local people participations properly and effectively rather it was a display of selective-elite-led stakeholders consultations and exclusionary by nature (Zakaria, 2018). Thus, the forestry conditions remain largely the same.

SDM, by its nature, addresses most of these issues in any policy making and implementation process. It ensures that all stakeholders participate at every step and stage in drafting a SFM strategy for Sylhet, Bangladesh. Since objectives play a core part of a fruitful decision sketch, the research team was very much successful to organize stakeholders around one table through FGDs to brainstorm on possible fundamental objectives, ending up with four, which can reverse deforestation in Sylhet, Bangladesh through to varying extent. These objectives are interconnected, however, completely independent in achievng the particular goal to be achieved. From formulating objectives to trade-off, the stakeholders drew every directive logically and concomitantly. The underlying principle of SDM is based on a combination of the 
bottom-up and top-down approaches in decision making. From this premise, the group addressed SDM as a holistic and all-inclusive platform for policy deliberation and participation. This platform reverses the policy making process from state centric to people centric. It provided an interactive framework for group consultation and integration of alternatives based on scientific explanations and valued based judgments. The team tried to accommodate the voices of all stakeholders but actually, the SDM exercise is not an easy task, especially when considering the presence of a multitude of stakeholders. One serious challenging aspect encountered during the exercise was the problem of reliability and authenticity of some existing information regarding the forestry sector of Bangladesh. In some cases, different sources provided different information regarding the same issues. These constitute part of the knowledge gaps and uncertainties of the SDM process presented in this research.

With any decision making process under any circumstances, the existence of uncertainties is often almost unavoidable. Political culture, regime change and shifts in philosophy of politics are regarded as major sources of uncertainties surrounding the smooth realization of any forestry policy goals. The political willingness at any point in time remains uncertain. For example, the last parliamentary elections debates in Bangladesh broadcasted and organized by many electronic media outlets and but the debates failed to raise environmental concerns. This is a clear indication that, in Bangladesh, elections are won or lost predominantly based on political or economic pronouncements of political parties, not on standpoints regarding environmental issues.

Economic uncertainty however, is still another big issue which may hamper outcomes of the SDM process at any time whatever Bangladesh's policy or plan may be. Bangladesh is highly dependent on external funding to carry out forestry and other programs. Forest Carbon Partnership Facility (FCPF), USAID, and the World Bank are the major sources of finance in the forestry sector of Bangladesh (Ministry of Environment and Forest, 2015). If there is no international financial support, there might be no projects in this sector. Disruption of those funds or redirection of funds to other needs can have significant negative effects on many environmental and sustainability initiatives. More so, success depends on cooperation and commitment from all competitive political parties, maintenance of effective program implementations amidst changing political cultures, and proper prioritizations and fund allocations. This justifies why the group agreed that, management issue is the prime concern for Bangladesh's forestry sector. Besides, corruption may also play a vital role to make this effort vulnerable at any stage of implementation. Bribery, nepotism, and favoritism are common corrupt practices in Bangladesh that may ruin the effectiveness of any policy product. For instance, in the implementation of sanctions against encroachers, the law enforcement agents may overlook the illegal actions of their relatives and friends, as well as, accepting financial bribes in some cases. Additionally, education, which a key process through which the citizens learn about the benefits of efficient forest resource use could be achieved. However, whether the people will live according to what they learn and practice alternative livelihood options to reduce dependency on forest resources remain highly uncertain. Furthermore, changing weather conditions can also pose an uncertain future because, without a proper understanding of climatic and soil conditions, afforestation efforts could become failed initiatives as well. Lastly, enforcing mandatory afforestation and land reclamation programs for mining and logging companies with strict compliance could be dramatically protested by these companies. These uncertainties prompted the group to revisit their fundamental objectives to create alternatives.

In evaluating alternatives, scientists and policy makers have to develop a more sophisticated approach toward understanding uncertainties than they have traditionally used. Rather than 
simply testing and rejecting individual hypotheses, scientists and decision makers must consider diverse sets of alternative hypotheses. Alternatives need to be continually revised, modified, and discarded, based upon how they fare in tests against empirical data (Hilborn and Mangel, 1996). In developing alternatives, the team considered a holistic and integrated approach by respecting the various positions of the stakeholders and covering all of the fundamental objectives as the table below represents.

Table 7: Creating Alternatives

\begin{tabular}{|c|c|c|c|}
\hline Alternatives & Means & Performance Measures & Consequences \\
\hline $\begin{array}{l}\text { Alternative "A": (Safe } \\
\text { guarding forest by } \\
\text { improving forest } \\
\text { management) }\end{array}$ & $\begin{array}{l}\text { Improve: Management on } \\
\text { forest resources (very }+ \text { ), } \\
\text { management on forest and } \\
\text { land degradation (very }+ \text { ), } \\
\text { and management on the state } \\
\text { of biodiversity (very }+ \text { ) }\end{array}$ & $\begin{array}{l}\text { i. Number of competent } \\
\text { personnel trainedeach year to } \\
\text { fill vacancies } \\
\text { ii. Availability of required } \\
\text { logistics in eachmanagement } \\
\text { unit }\end{array}$ & Very + \\
\hline $\begin{array}{l}\text { Alternative “B”: (Safe } \\
\text { guarding forest via } \\
\text { limited dependence) }\end{array}$ & $\begin{array}{l}\text { Minimize dependence on forest } \\
\text { resources }(+), \text { improve forest } \\
\text { management }(+) \text {, minimize } \\
\text { forest and land degradation } \\
(+) \text {, maintain state of } \\
\text { biodiversity }(\mathbf{0})\end{array}$ & $\begin{array}{l}\text { i. Availability of alternative } \\
\text { sources of } \\
\text { livelihood } \\
\text { ii. Number of people engaged in } \\
\text { alternativesources of livelihood }\end{array}$ & + \\
\hline $\begin{array}{l}\text { Alternative "C": (Safe } \\
\text { guarding forest through } \\
\text { reclamation) }\end{array}$ & $\begin{array}{l}\text { Minimize forest and land } \\
\text { degradation }(+), \text { improve } \\
\text { forest management (very }+ \text { ), } \\
\text { minimize dependence on forest } \\
\text { resources (+), improve state of } \\
\text { biodiversity (+) }\end{array}$ & $\begin{array}{l}\text { i. Size of land reclaimed in } \\
\text { hectares } \\
\text { ii. Number of trees plant }\end{array}$ & + \\
\hline $\begin{array}{l}\text { Alternative "D": } \\
\text { (Maximizing benefits } \\
\text { from forest resources) }\end{array}$ & $\begin{array}{l}\text { Maintain state of biodiversity } \\
(\mathbf{0}) \text {, maintain forest } \\
\text { management (-), maintain } \\
\text { dependence on forest } \\
\text { resources (-), maintain forest } \\
\text { and land degradation }(-)\end{array}$ & $\begin{array}{l}\text { i. Income derived from forest } \\
\text { resources } \\
\text { ii. Number of people employed } \\
\text { in forestry } \\
\text { sector }\end{array}$ & - \\
\hline
\end{tabular}

\section{Source: Constructed from the FGDs (2017-18)}

As clearly seen, each alternative covers all the fundamental objectives, using a value focused thinking approach to make them simple and clear. Alternative " $A$ " aims at improving forest management, while alternative " $\mathrm{D}$ " aims at maximizing benefits from the forest especially financial benefits for illegal operators, and logging and mining industries. Using alternatives "A" and " $D$ " as extremes, different iterations were done to come out with other alternatives. The iterations were simply a combination of the different fundamental objectives at different levels, keeping in mind the overall objectives and the interest of the various stakeholders. The different levels of combinations involved three possibilities: improving a fundamental Objective, maintaining the other, and minimizing another. Using these iterations interchangeably, it was possible to draw up many alternatives. However, for the sake of the overall objectives and to enhance an effective trade-off process given that there are also four fundamental objectives, only four alternatives were considered. The team placed more emphasis on the overall consequences rather than cost-benefit analysis to avoid the complexity in comparing alternatives with the fundamental objectives. By so doing, it is believed that, if any stakeholder sees the consequence tables of the fundamental objectives (table-6), and 
alternatives (table 7) combined, it would be relatively easier to make tradeoffs and to suggest an alternative or groups of alternatives that could best serve Sylhet, Bangladeshi quest to address deforestation. The research, therefore suggested the following: Maximizing forest management, minimizing dependence on forest resources, and Alternative ' $A$ ' (Safe guarding forest by improving forest management), based on predicted outcomes, as they will bring the highest positive impacts towards realizing SFM in Sylhet, Bangladesh. A combination of the other objectives and alternatives is also possible except for alternative "D". However, they might not be very positively based on the consequences of their predicted outcomes.

\section{CONCLUSION}

It has been seen that Sylhet, Bangladesh has one of the highest deforestation rates in Asia. The SDM approach in this paper focused more on the immediate causes because they are more visible granted that they directly result to forest loss in Sylhet, Bangladesh. One of the first steps of the SDM process, the identification of stakeholders, recognized different stakeholder groups to be included in the policy formulation because their benefits, whether positive or negative, would be influenced by any new policies geared towards addressing deforestation in Sylhet, Bangladesh. After determining the fundamental objectives, objectives hierarchy has been established by applying the tool of pair wise ranking to guide decision on the most influential fundamental objective of maximizing forest management. Means objectives and process objectives have also been determined in the process. As for the PMs, natural PMs have been used for all the means objectives in order to make them direct, clear, and comparable.

In order to avoid some predictable risk, recognizing the uncertainties for each of these objectives were necessary during this process. In the trade-off process, with the usage of consequences predicting scale, and comparison between the fundamental objectives and the alternatives, two fundamental objectives and one alternatives are likely to have very positive impacts for addressing deforestation in Sylhet, Bangladesh: Maximizing forest management, minimizing dependence on forest resources, and Alternative 'A' (Safe guarding forest by improving forest management). Maximizing forest management includes improving forest managements and instituting new management policies. Improving forest management simply improves management efficiency.

One major weakness of applying the SDM approach to achieve sustainable forest management in Sylhet, Bangladesh is identifying the uncertainties. The situation of Bangladesh shows that forests play an important role in the economy and the livelihood of a great number of people depends on forest resources. Hence, a comprehensive prediction of risks on applicability of the new policies remains a daunting challenge. There is so much difficulty of convincing stakeholders regarding new policies because of uncertainties. However, by taking account of different stakeholders and making the alternatives comparable and understandable, SDM can be practically used not only in the field of sustainable forest management, but also in resolving other environmental problems.

\section{Anknowledgement:}

This paper is the outcome of a research project funded by SUST Research Centre, Shahjalal University of Science \& Technology, Sylhet-3114, Bangladesh (Grant Code: SS-17). Thank you SUST Research Centre. I remember Yingzhong Diao, Ernest C. Nwanguma, Benjamin Dosu Jnr, Yaw Adom-Frempah, and Michael Van Zyll De Jong of EPI, Grenfell, Memorial University, Canada for their initial contributions in exploring the applicability of SDM in the field of the forest. 


\section{References}

Achard, M. P., Richards T., Javier Gallego, Hugh D. Eva1, Hans J. Stibig, and Jean-Paul Malingreau (2002).

Determination of Deforestation Rates of the World's Humid Tropical Forests. Science Journal, Vol. 297

Alpert, P. (1993). Conserving Biodiversity in Cameroon. Ambio 22(1): 44-49.

Angelsen, A. and D. Kaimowithz (1999). Rethinking the Causes of Deforestation: Lessons from Economic Models. The Word Bank Research Observer. 14:73-98

Appiah, M. (2013). Understanding the Complexities and Resource Sustainability in Afram Plains, Bangladesh. Environmental Management and Sustainable Development, 2(1)

Boafo, J. (2013). The Impact of Deforestation on Forest Livelihoods in Bangladesh. The Asia Portal backgrounder series. No 49.

Burns, A.; Burns, R. (2008). Basic Marketing Research (Second Ed.). New Jersey: Pearson Education. ISBN 978-013-205958-9

Christopher, A., Christopher A., and Christopher, E. (2007). Likert Scales and Data Analyses. Quality Progress.

Chowdhury, K. J., Biswas. R. S., Islam. S. M., Rahman, O. and Uddin, N. S. (2004). Biodiversity of Ratargul Swamp Forest, Sylhet, IUCN Bangladesh Office.

Chowdhury, K. J. and Hossain, A. A. M. (2011). Bangladesh Forestry Outlook Study, Asia Pacific Forestry Outlook Study II, FAO Office Bangkok. Working Paper No. APFSOS II/ WP/ 2011/ 33

David, H.A. (1988). The Method of Paired Comparisons. New York: Oxford University Press.

Domson, O. and Vlosky, R. P. (2007). A Strategic Overview of the Forest Sector in Bangladesh. Louisiana Forest Products Development Center Working Paper \#81

European Union (2010). Study on the evolution of some deforestation drivers and their potential impacts on the costs of an avoiding deforestation scheme, Final Report. Framework Contract No. DG ENV/G.1/FRA/2006/0073

FAO (2014). FAO Sets Standards to Improve National Forest Monitoring System. Retrieved from Food and Agriculture Organization of the United Nations Website:

http://www.fao.org/news/story/en/item/254098/icode/

FAO (2010) Global Forest Resources Assessment 2010. FAO, Rome, Italy

Food and Agriculture Organization (FAO) (2004). Global forest resources assessment update 2005 Terms and definitions (Final version), Foodand Agriculture Organization of the United Nations, Rome. Available at: http://www.fao.org/docrep/007/ae156e/AE156E00.htm\#TopOfPage. Date Accessed: 20/10/2014.

FA0. (2006). Global Forest Resources Assessment 2005. Progress towards sustainable forest management. FAO Forestry Paper, 147pp, 320 pp.

FAO (2001). Deforestation continues at a High Rate in Tropical Areas, State of World's Forests. FAO, Rome, Italy.

Geist, J.H., Lambin, F.E., 2002. Proximate causes and underlying driving forces of tropical deforestation. Bioscience $52,143-150$.

Gregory, R., Failing, I, Harstone, M, Long, G., McDaniels, T., Ohlson (2012). Structured Decision Making. A Practical Guide to Environmental Management Choices. First Edition. Blackwell Publishing Ltd

Government of Bangladesh. (2016). Forestry Master Plan 2017-36, Bangladesh Forest Department

Hilborn, R., and M. Mangel. (1996). The Ecological Detective: Confronting Models with Data. Princeton University Press, Princeton, New Jersey, USA

Houghton, R.A., (2005). Tropical deforestation as a source of greenhouse gas emissions. In: Mutinho, P., Schwartsman, S. (Eds.), Tropical Deforestation and Climate Change. IPAM (Instituto de Pesquisa Ambiental da Amazonia) and Environmental Defense, Washington, DC, USA, pp. 13-22.

Maser, C. (1994). Sustainable Forestry Philosophy, Science, and Economics, St. Lucie Press, USA.

Ministry of Environment and Forests. (2015). UN-REED Program. Department of Forest

North American Aerospace Defend Command (1999). The Logical Framework Approach, Handbook for Objectives-Oriented Planning. Fourth edition. ISBN 82-7548-160-0.

Siaw, D. (2001). State of Forest Genetic Resources in Bangladesh. FAO, IPGRI/SAFORGEN, DFSC and ICRAF, Forest Genetic Resources, Working Paper 17. 
Zakaria, A. F. M. (2020). An Application of Structured Decision Making Process in Approaching Deforestation and Promoting Sustainable Forest Management of Sylhet, Bangladesh. Advances in Social Sciences Research Journal, 7(1) 525-542.

United Nations Environment Program (UNEP) (2002). Asia Environment Outlook. Past, present and future perspectives. UNEP, Nairobi, Kenya. Pp131

Yiridoe, E. K. and Nanang, D. M. (2001). An Econometric Analysis of the Causes of Deforestation: Bangladesh. Selected Paper presented at American Agricultural Economics Association Conference, August 5-8, 2001, Chicago, IL.

Zakaria, AFM. (2018). Politics of Inclusion and Ecological Modernization: Insight into the UNREED+ Program of Bangladesh, IJMT, Vol.7, No. 2 